\title{
COMUNICAÇÃO
}

\section{TAMANHOS E POSIÇÕES DE EXPLANTES E VOLUMES DE MEIO DE CULTIVO NA MULTIPLICAÇÃO DE IPECA (Psychotria ipecacuanha (Brot.) Stokes) IN VITRO}

\author{
Explant sizes and positions and volume of medium of culture on the \\ multiplication of Ipecac (Psychotria ipecacuanha (Brot.) Stokes) in vitro \\ Érika Soares Reis ${ }^{1}$, José Eduardo Brasil Pereira Pinto ${ }^{2}$, \\ Ricardo Monteiro Corrêa ${ }^{3}$, Suzan Kelly Vilela Bertolucci ${ }^{4}$, Osmar Alves Lameira ${ }^{5}$
}

\begin{abstract}
RESUMO
No presente trabalho, avaliaram-se o efeito do tamanho e posição de explantes na planta de ipeca e diferentes volumes de meio de cultivo na multiplicação "in vitro" de Psychotria ipecacuanha (Brot.) Stokes. O experimento que avaliou o efeito dos diferentes tamanhos e posições de explantes foi conduzido em tubos de ensaio de 25x150 mm, contendo $20 \mathrm{~mL}$ de meio de cultivo por tubo, sendo avaliados os tamanhos de 0,$5 ; 1,0$ e $1,5 \mathrm{~cm}$ nas posições basal, mediana e apical. No segundo experimento, utilizaram-se frascos nos quais os tratamentos consistiam nos volumes de 10, 20, 30 e $40 \mathrm{~mL}$ de meio de cultivo por frasco. O meio de cultivo utilizado nos dois experimentos foi o MS (MURASHIGE e SKOOG, 1962) acrescido de 1,5 mg. $\mathrm{L}^{-1}$ de BAP (6-benzilaminopurina). A posição do segmento internodal não influenciou o desenvolvimento vegetativo; os tamanhos de 1,0 e $1,5 \mathrm{~cm}$ apresentaram maior número de brotações que os segmentos com $0,5 \mathrm{~cm}$. No experimento com diferentes volumes de meio de cultivo, observou-se que 30 e $40 \mathrm{~mL}$ foram significativamente melhores na indução de brotações adventícias nessa espécie.
\end{abstract}

Termos para indexação: Psychotria ipecacuanha, planta medicinal, segmento internodal.

\begin{abstract}
In this work evaluated the effect of size and position of explant in plant and volume different culture medium on the multiplication of Psychotria ipecacuanha (Brot.) Stokes "in vitro" conditions. Experiment with different size and positions was conducted in test tube of $25 \times 150 \mathrm{~mm}$, content $20 \mathrm{~mL}$ of culture medium with 0,$5 ; 1,0$ and $1,5 \mathrm{~cm}$ of size and three different positions (basal, median and apical). In the second experiment were utilized differents volumes (10, 20, 30 and $40 \mathrm{~mL})$ of culture medium. Culture medium utilized on two experiments was MS (MURASHIGE and SKOOG, 1962) supplemented with $1,5 \mathrm{mgL}^{-1}$ of BAP (6-benzilaminopurine). The differents position not observed influenced, where size of 1,0 and 1,5 showed higher numbers of shoots segments. The different volumes of culture medium were observed that 30 and $40 \mathrm{~mL}$ showed higher shoot number.
\end{abstract}

Index terms: Psychotria ipecacuanha, medicinal plant, internodal segment.

(Recebido para publicação em 31 de outubro de 2002 e aprovado em 15 de agosto de 2003)

Psychotria ipecacuanha (Brot.) Stokes é conhecida popularmente por ipeca ou poaia. É uma planta herbácea, com $50 \mathrm{~cm}$ de altura, perene, pertencente à família Rubiaceae (VIEIRA, 1991). Nativa da floresta do Brasil, a ipeca é encontrada na Amazônia sob árvores de grande porte. São produzidos em suas raízes dois alcalóides de grande valor farmacológico, que são a emetina e a cefalina. Essas substâncias apresentam efeito emético considerável e expectorante em doses atenuadas, sendo utilizadas nos tratamentos da amebíase e disenteria (SOUZA et al., 1991).

A ipeca está ameaçada de extinção no Brasil, em razão da coleta indiscriminada. A propagação não é feita por sementes, por serem recalcitrantes; por isso, a

\footnotetext{
1. Acadêmica do curso de Agronomia - Universidade Federal de Lavras/UFLA, Caixa Postal 37 - 37200-000 - Lavras, MG. Bolsista de Iniciação Científica, CNPq.

2. Engenheiro Agrônomo, PhD, Professor do Departamento de Agricultura da UFLA. jeduardo@ufla.com.br

3. Engenheiro Agrônomo, UFLA

4. Farmacêutica, Msc, Professora, UFLA

5. Engenheiro Agrônomo, EMBRAPA/CPATU - Caixa Postal 48 - Amazônia Oriental/Belém, PA.
} 
cropropagação é uma alternativa vantajosa. As plantas provenientes de sementes atingem um maior teor de alcalóides no terceiro a quarto ano de cultivo, ao passo que, de acordo com Costa (2000), as raízes advindas de micropropagação e que receberam solução nutritiva alcançaram um teor de 2,32\% de emetina com 12 meses de cultivo.

Em alguns trabalhos, verifica-se a influência da posição do explante e do volume do meio na multiplicação.

De acordo com Roest e Bokelmann (1981), explantes de cravo provenientes do campo apresentaram taxa de regeneração de brotos de 88,6 e $69,8 \%$, respectivamente, para segmentos da parte apical e basal. Hollings e Stone (1968) reportaram que a regeneração de broto do ápice foi de $32 \%$, ao passo que de broto lateral foi de $18 \%$. Entretanto, em trabalhos em que se utilizam gemas axilares têm mostrado um bom desenvolvimento vegetativo (ANCORA et al., 1981; GUPTA et al., 1981; MCCOMB e NEWTON, 1981).

Nesse sentido, objetivou-se com este trabalho avaliar a influência do tamanho e posição de segmento internodal, e também verificar diferentes volumes de meio de cultivo na multiplicação in vitro de $P$. ipecacuanha.

Foram utilizados segmentos internodais provenientes de plântulas de ipeca Psychotria ipecacuanha (Rubiales, Rubiaceae), obtidas da cultura de gemas de raiz estabelecidas "in vitro" no Laboratório de Cultura de Tecidos Vegetais da EMBRAPA/Amazônia Oriental (CPATU), sub- cultivadas no Laboratório de Cultura de Tecidos Vegetais do Departamento de Agricultura da Universidade Federal de Lavras. Esse subcultivo foi efetuado em meio MS (MURASHIGE e SKOOG, 1962) com 3\% de sacarose, acrescido de 2,0 mg. $\mathrm{L}^{-1}$ de BAP, alternado com o mesmo meio de cultura, porém, acrescido de $0,5 \mathrm{mg} . \mathrm{L}^{-1}$ de $\mathrm{GA}_{3}$ (ácido giberélico) em tubos de ensaio $(25 \times 150 \mathrm{~mm})$ e inoculados a $26+1^{\circ} \mathrm{C}$, num fotoperíodo de 16 horas luz sob $25 \mu$ mol. $\mathrm{m}^{-2} . \mathrm{s}^{-1}$ de irradiância em sala de crescimento.

Foram realizados dois experimentos, a saber:

Experimento I: Influência dos diferentes tamanhos e posições dos segmentos internodais de plântulas de $P$. ipecacuanha (Tabela 1).

$\mathrm{O}$ ensaio foi conduzido em meio de cultura MS semi-sólido (6 g/L de agar), suplementado com 1,5 mg. $\mathrm{L}^{-1} \mathrm{de}$ BAP (6-benzilaminopurina). Foram utilizados tubos de 25 x $150 \mathrm{~mm}$, contendo cerca de $20 \mathrm{~mL}$ de meio de cultura, autoclavados a $120^{\circ} \mathrm{C}$ sob $1 \mathrm{~atm}$ por 20 minutos.

Os segmentos internodais com seus respectivos tamanhos e posições foram retirados de plântulas de ipeca pré-estabelecidas em sala de crescimento. Em seguida, foram inoculados em posição horizontal no meio de cultivo em câmara de fluxo laminar devidamente esterilizada. Os segmentos internodais desenvolveram-se em sala de crescimento com fotoperíodo de 16 horas/dia, à temperatura constante de $26 \pm 1^{\circ} \mathrm{C}$ e intensidade luminosa de $25 \mu \mathrm{mol} . \mathrm{m}^{-2}$. $\mathrm{s}^{-1}$.

TABELA 1 - Tamanhos e posições de explantes (segmentos internodal) utilizados em cultivo in vitro de ipeca. UFLA, 2002.

\begin{tabular}{ccc}
\hline Tratamentos & Tamanho do segmento internodal (cm) & Posição do segmento internodal na plântula \\
\hline 1 & 0,5 & basal \\
2 & 0,5 & mediana \\
3 & 0,5 & apical \\
4 & 1,0 & basal \\
5 & 1,0 & mediana \\
6 & 1,0 & apical \\
7 & 1,5 & basal \\
8 & 1,5 & mediana \\
9 & 1,5 & apical \\
\hline
\end{tabular}

Ciênc. agrotec., Lavras, v. 28, n. 3, p. 703-709, maio/jun., 2004 
Experimento II: Influência de diferentes volumes de meio de cultivo na formação de brotos em segmentos internodais de $P$. ipecacuanha (Tabela 2).

$\mathrm{O}$ ensaio foi conduzido em meio de cultura MS semi-sólido com 6 g.L $\mathrm{L}^{-1}$ de ágar suplementado com 1,5 mg. L $^{-1}$ de 6-benzilaminopurina (BAP). Foram utilizados frascos de $200 \mathrm{~mL}$ contendo diferentes volumes de meio autoclavados a $120^{\circ} \mathrm{C}$, sob $1 \mathrm{~atm}$ por 20 minutos.

Posteriormente, os segmentos internodais de tamanho médio de um centímetro foram retirados de plântulas de ipeca pré-estabelecidas em sala de crescimento e inoculados em posição horizontal nos frascos, contendo os diferentes volumes de meio, conforme a Tabela 2, com quatro segmentos por frasco em câmara de fluxo laminar devidamente esterilizada.

Em seguida, os frascos foram mantidos em sala de crescimento com um fotoperíodo de 16 horas/dia, à temperatura constante de $26 \pm 1^{\circ} \mathrm{C}$ e intensidade luminosa de $25 \mathrm{~mol} \cdot \mathrm{m}^{-2} \cdot \mathrm{s}^{-1}$.

Após sessenta dias do estabelecimento de cada experimento, foi feita a primeira avaliação e, após noventa dias, a segunda. Para efeito de análise, foi considerada a avaliação realizada aos 90 dias. A variávelresposta analisada foi número de brotações por tubo no experimento I e, por frasco, no experimento II.

O delineamento estatístico nos dois experimentos foi o inteiramente casualizado com cinco repetições. No experimento I, cada repetição foi composta por quatro segmentos nodais, e no experimento II, por quatro frascos com quatro segmentos nodais por frasco.

Os dados obtidos foram submetidos à análise de variância, sendo as médias comparadas pelo teste Scott \& Knott a 5\% de probabilidade.

TABELA 2 - Efeito de diferentes volumes de meio de cultivo na formação de brotos de ipeca. UFLA, 2002.

\begin{tabular}{cc}
\hline Tratamentos & Volumes $(\mathbf{m L})$ \\
\hline 1 & 10 \\
2 & 20 \\
3 & 30 \\
4 & 40 \\
\hline
\end{tabular}

Tem sido verificado que as taxas de sobrevivência, de crescimento e de multiplicação de ramos, nos mais variados tipos de explantes, dependem do tama- nho do explante inicial (MURASHIGE, 1977; NARAYANASYAMY, 1977; TISSERAT, 1985).

No experimento em que se utilizou diferentes tamanhos de segmentos internodais, observou-se que os tamanhos de 1,0 e 1,5 cm apresentaram maior número de brotos em relação a $0,5 \mathrm{~cm}$ e que as posições basais, medianas e apicais não influenciaram na regeneração de brotações (Figura 1). Com isso, infere-se que há tamanhos ideais de explantes para dar início às culturas in vitro; explantes muito pequenos não sobrevivem bem em cultura, ao passo que os maiores são de descontaminação mais ineficiente, considerando-se, ainda, que, no caso de explantes constituídos de extremidades de ramos, a proporção de plantas geneticamente aberrantes parece ser superior nos explantes de maior tamanho (MURASHIGE, 1977).

Em outros trabalhos de autoria de Norton e Norton (1986), nos quais estudaram-se os diferentes tamanhos de ápices caulinares de Prunus, observou-se que o número de brotos produzidos aumentou à medida que se aumentava o tamanho dos explantes.

Pela Figura 2 pode-se observar que os segmentos de 1 e $1,5 \mathrm{~cm}$ proporcionaram o maior número de brotações de ipeca, não diferindo entre si estatisticamente. Pierik (1990) afirmou que é muito mais difícil induzir o crescimento em estruturas muito pequenas, como células, agregados de células e meristemas. Em estruturas maiores, como explantes de folha, caule ou tubérculo, e cada fração isolada de uma planta tem sua própria porção de reservas e hormônios, quanto maior o seu fragmento vegetal, mais fácil é induzir o crescimento e regeneração.

Isso pode ser evidenciado no presente trabalho, já que segmentos internodais pequenos $(0,5 \mathrm{~cm})$ tinham baixa capacidade de produzir brotos, em comparação aos segmentos maiores $(1,0$ e 1,5 cm).

As diferentes posições de segmentos internodais (basal, mediana e apical) não interferiram na formação de brotos de P. ipecacuanha (Figura 3), nos quais estatisticamente não houve diferença significativa.

As posições basais, medianas e apicais de gemas provenientes de plântulas de Ipomoea batatas (L.) Poir. não influenciaram no desenvolvimento in vitro dessa espécie (ALVES, 1992).

Em contrapartida, Evers (1984) concluiu que as posições basais de Pseudotsuga menziesii (Mirb.) Franco mostraram um menor desenvolvimento in vitro, em que as gemas terminais cresceram mais rapidamente que as gemas axilares. 
Em outras espécies como Citrus aurantium (L.), Bouzid (1975) observou que segmentos nodais e internodais provenientes da porção mediana do ramo apre- sentaram maior formação de gemas, comparativamente às posições basal e apical, e que a região basal foi a que apresentou menor formação de gemas.

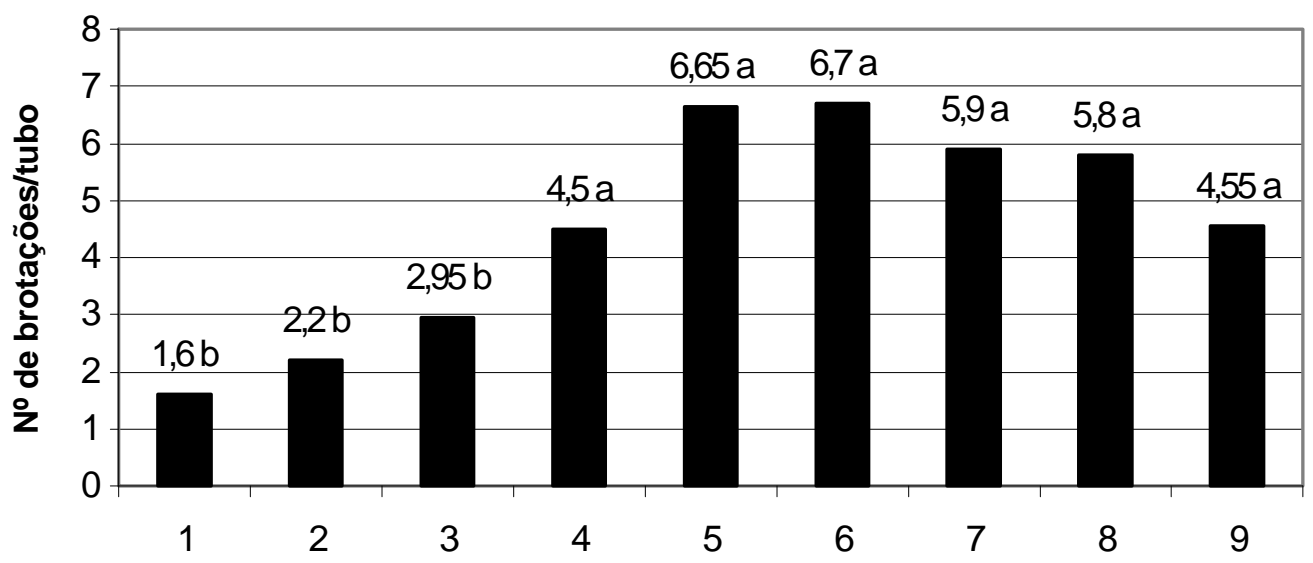

Tratamentos

FIGURA 1 - Relação entre o número médio de brotações/tubo e os tratamentos: 1) posição basal com $0,5 \mathrm{~cm}$ de comprimento; 2) posição mediana com $0,5 \mathrm{~cm}$ de comprimento; 3) posição apical com $0,5 \mathrm{~cm}$ de comprimento; 4) posição basal com $1,0 \mathrm{~cm}$ de comprimento; 5) posição mediana com $1,0 \mathrm{~cm}$ de comprimento; 6) posição apical com $0,5 \mathrm{~cm}$ de comprimento; 7) posição basal com $1,5 \mathrm{~cm}$ de comprimento; 8) posição mediana com $1,5 \mathrm{~cm}$ de comprimento; 9) posição apical com 1,5 cm de comprimento. Os valores não seguidos de mesma letra diferem entre si pelo teste de Scott \& Knott, a $5 \%$ de probabilidade de erro.

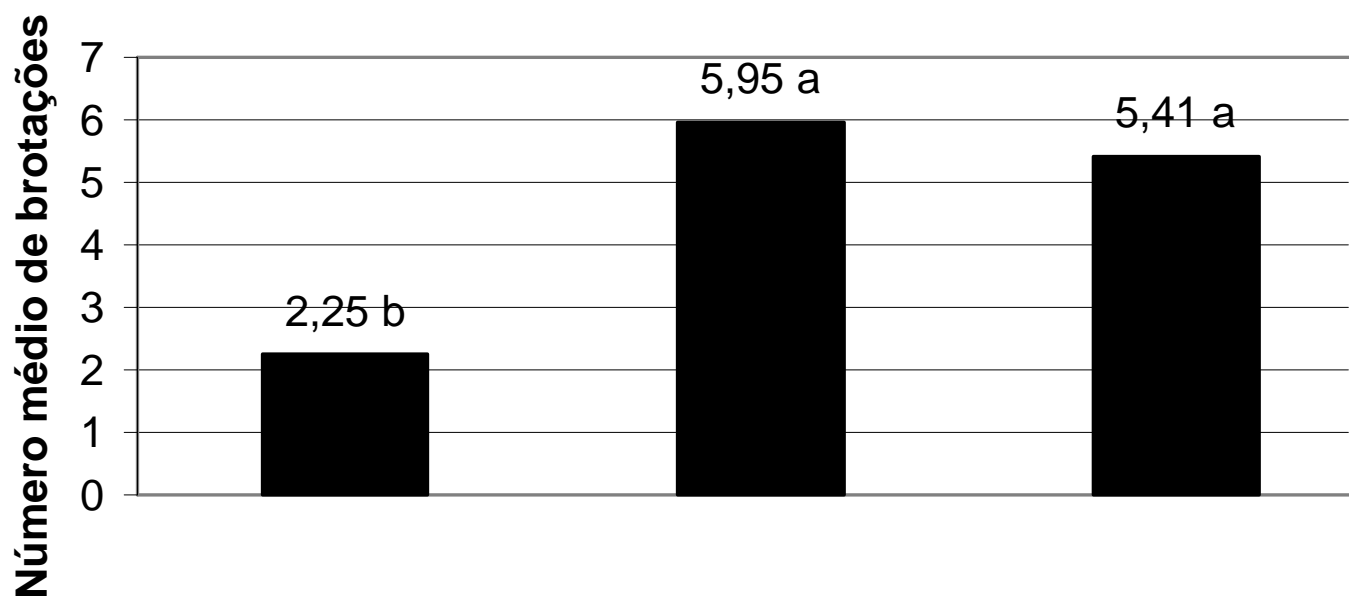

Comprimento dos segmentos internodais $(\mathrm{cm})$

FIGURA 2 - Relação entre o número médio de brotações e o tamanho dos segmentos internodais: 1) 0,5 cm; 2) $1,0 \mathrm{~cm}$; 3) 1,5 cm; sem levar em consideração a posição dos segmentos.

Ciênc. agrotec., Lavras, v. 28, n. 3, p. 703-709, maio/jun., 2004 
No experimento em que se analisaram os diferentes volumes de meio de cultura, pode-se observar que os volumes de 30 e $40 \mathrm{~mL}$ foram significativamente melhores que os volumes de 10 e $20 \mathrm{~mL}$, ou seja, os segmentos presentes nos frascos que continham 30 e 40 $\mathrm{mL}$ apresentaram maior número de brotações (Figura 4).

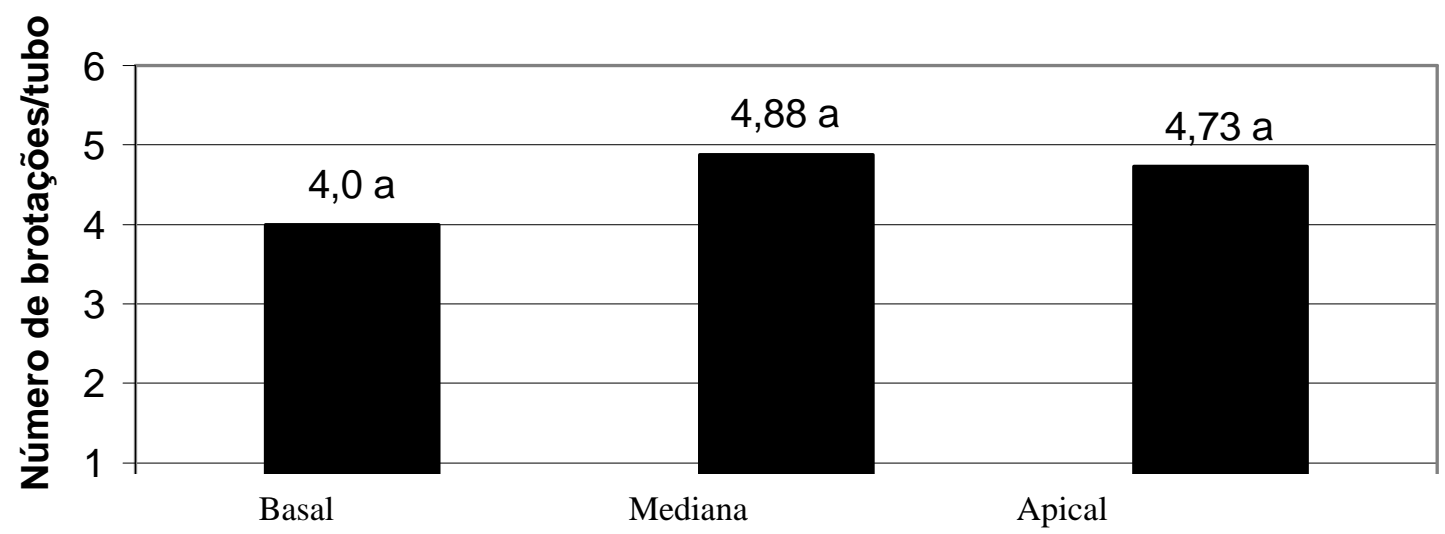

Posições dos segmentos internodais da planta

FIGURA 3 - Número médio de brotações por tubo de segmentos internodais retirados das posições basal, mediana e apical, sem levar em consideração o tamanho dos segmentos.

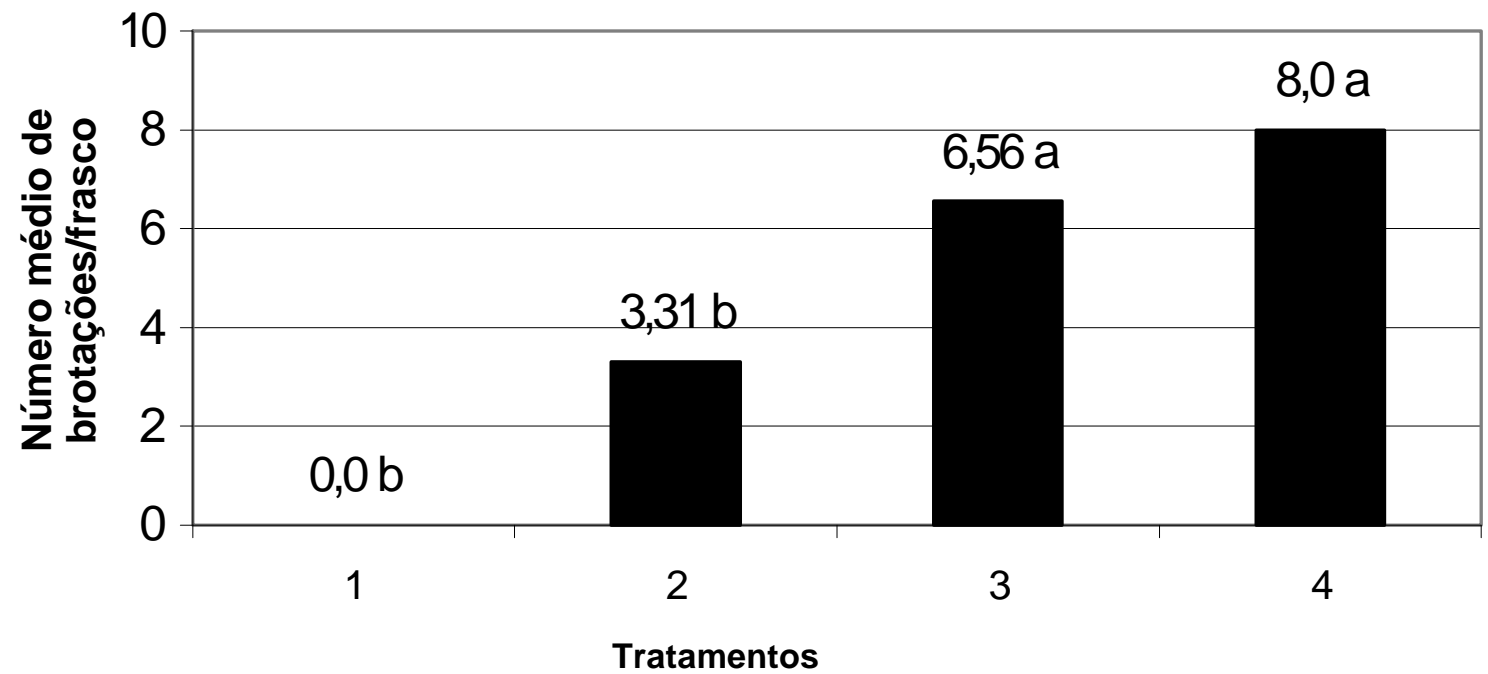

FIGURA 4 - Número médio de brotações por frasco e os tratamentos: 1) $10 \mathrm{~mL}$ de meio de cultivo; 2) $20 \mathrm{~mL}$ de meio de cultivo; 3) $30 \mathrm{~mL}$ de meio de cultivo; 4) $40 \mathrm{~mL}$ de meio de cultivo. Os valores não seguidos de mesma letra diferem entre si pelo teste de Scott \& Knott a 5\% de probabilidade de erro. 
Contrariamente, outros autores, como Carvalho et al. (1995), estudando a influência de fatores físicos no desenvolvimento e crescimento in vitro de batatadoce (Ipomoea batatas), verificaram que $10 \mathrm{~mL}$ de meio de cultura por frasco com quatro explantes proporcionaram maior formação de gemas em relação aos volumes de 20 e $30 \mathrm{~mL}$.

Como regra geral, quanto menor o explante, menor a quantidade de meio a ser utilizado. Para ápices caulinares de batata-doce e batata, $4 \mathrm{~mL}$ de meio líquido são suficientes para a diferenciação e crescimento inicial; entretanto, em culturas estabelecidas, a taxa de crescimento é diretamente proporcional à quantidade de meio (MURASHIGE, 1977).

Dessa forma, conclui-se que os segmentos internodais de 1,0 e $1,5 \mathrm{~cm}$ proporcionaram maior número de brotos que os segmentos de $0,5 \mathrm{~cm}$. No entanto, os explantes retirados das posições basal, mediana e apical produziram estatisticamente o mesmo número de brotos.

Um maior número de brotações de Psychotria ipecacuanha foi observado em volumes de meio de cultivo de 30 e $40 \mathrm{~mL}$.

\section{REFERÊNCIAS BIBLIOGRÁFICAS}

ALVES, J. M. C. Efeito da inibição correlativa e reguladores de crescimento na repicagem de plântulas de batata-doce (Ipomoea batatas (L.) Lam) obtidas através da cultura de meristema. Revista Ciência e Prática, Lavras, v. 16, n. 3, p. 349-357, jul./set. 1992.

ANCORA, G.; BELLI-DOMINI, M. L.; CUOZZO, L. Globe artichoke plants obtained from shoot apices through rapid in vitro micropropagation. Scientific Horticulture, Wye, v. 14, p. 207-213, 1981.

BOUZID, S. Quelques traits du comportment de boutures de Citrus en culture in vitro. Comptes Rendus Hebdomadaires des Seances de l'Academie des Sciences, [S.1.], v. 280, n. 14, p. 1689-1692, 1975.

CARVALHO, R.; FAVARETTO, N.; PINTO, J. E. B.; DESCHAMPS, C.; INNECCO, R. Influência de fatores físicos no desenvolvimento e crescimento in vitro de batata-doce [Ipomoea batatas (L.) Poir]. Revista Ciência e Prática, Lavras, v. 19, n. 2, p. 158-164, abr./jun. 1995.
COSTA. Crescimento e teor de emetina em plantas de ipeca (Cephaelis ipecacuanha A. Richard) obtidas in vitro e submetidas às condições de soluções nutritivas em casa de vegetação. Revista Ciência e Prática, Lavras, v. 24, n. 1, p. 46-53, jan./mar. 2000.

EVERS, A. Growth and morphogenesis of shoot initials of Douglas fir, Pseudotsuga mensiesii (Mirb.) franco in vitro. 1984. Article 1-6. Dissertation (Mcs at Agriculture) - University of Wageningen, Wageningen.

GUPTA, P. K.; MASCARENHAS, A. F.; JANNATHAN, V. Tissue culture of forest trees clonal propagation of mature trees of Eucalyptus citriodora. Hook, by tissue culture. Plant Scientific Letters, Limerick, p. 195-201, 1981.

HOLlingS, M.; STONE, O. M. Techniques and problems in the productions of virus tested plant material. Scientific Horticulture, Wye, p. 57-72, 1968.

McCOMB, J. A.; NEWTON, S. Propagation of Kangaroo paws using tissue culture. Journal of Horticultural Science, London, p. 181-183, 1981.

MURASHIGE, T. Clonal crops through tissue culture. In: BARZ, W.; REINHARD, E.; ZENCK, M. H. (Eds.). Plant tissue culture and its biotechnological application. New York: Springer-Verlag, 1977. p. 392-406.

MURASHIGE, T.; SKOOG, F. A revised medium for rapid growth and biossays with tobacco tissue cultures. Physiologia Plantarum, Copenhagen, v. 15, p. 473497, 1962.

NARAYANASYAMY, S. Regeneration of plants from tissue cultures. In: REINERT, J.; BAJAJ, Y. P. S. (Eds.). Plant cell, tissue and organ culture. New York: Springer-Verlag, 1977. p. 179206.

NORTON, M. E.; NORTON, C. R. Explant origin as the determinat of in vitro proliferation in Prunnus and Spiraea. Journal of Horticultural Science, Alexandria, v. 61, n. 1, p. 43-48, 1986.

PIERIK, R. L. M. Cultivo in vitro de las plantas superiores. 3. ed. Madrid: Mundi-Prensa, 1990. $326 \mathrm{p}$.

Ciênc. agrotec., Lavras, v. 28, n. 3, p. 703-709, maio/jun., 2004 
ROEST, S.; BOKELMANN, G. S. Vegetative propagation of carnation in vitro through multiple shoot development. Scientific Horticulture, Wye, p. 357-366, 1981.

SOUZA, M. P.; MATOS, M. E. O.; MATOS, F. J. A. Constituintes químicos ativos de plantas medicinais brasileiras. Fortaleza: EUFC, 1991. 416 p.
TISSERAT, B. Embryogenesis, organogenesis, and plant regeneration. In: DIXON R. A. (Ed.). Plant cell culture: a pratical approach. Oxford: IRL, 1985. p. 79105.

VIEIRA, L. S. Manual da medicina popular. Belém: Agronomia Vozes, 1991. 247 p. 